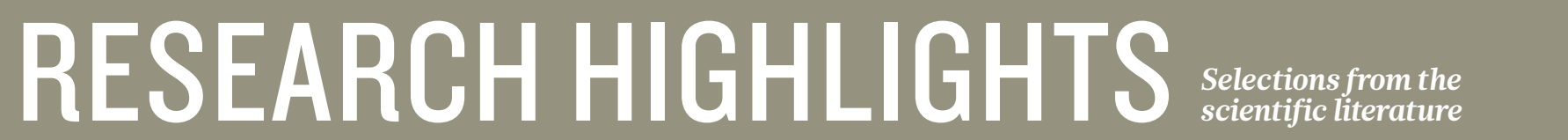

CANCER

\section{Tumour reined in by its neighbours}

Two groups have found that certain non-cancerous cells that surround a tumour in the pancreas keep it in check, even though these cells seem to boost other types of cancer.

Raghu Kalluri at the University of Texas MD Anderson Cancer Center in Houston and his colleagues deleted fibroblast cells, which are found in connective tissue, in a mouse model of pancreatic cancer. These animals had more aggressive tumours and died sooner than those with fibroblasts. These cells seem to help the immune system to fight the tumour. In human pancreatic tissue samples, those with fewer fibroblasts were associated with lower patient survival rates.

Kenneth Olive at Columbia University in New York, Ben Stanger at the University of Pennsylvania in Philadelphia and their colleagues also found that in animals that had fewer connective tissue cells in their pancreatic tumours, the tumours grew faster and had more blood vessels than in control mice.

The results could help to explain why certain drugs that target a tumour's neighbouring cells have failed in pancreatic cancer clinical trials, the authors say.

Cancer Cell http://doi.org/szg; http://doi.org/szh (2014)

IMMUNOLOGY

\section{Fetal cells have a good memory}

Immune cells that 'remember' past encounters with foreign molecules have been found in human umbilical cord blood, even though the fetal environment

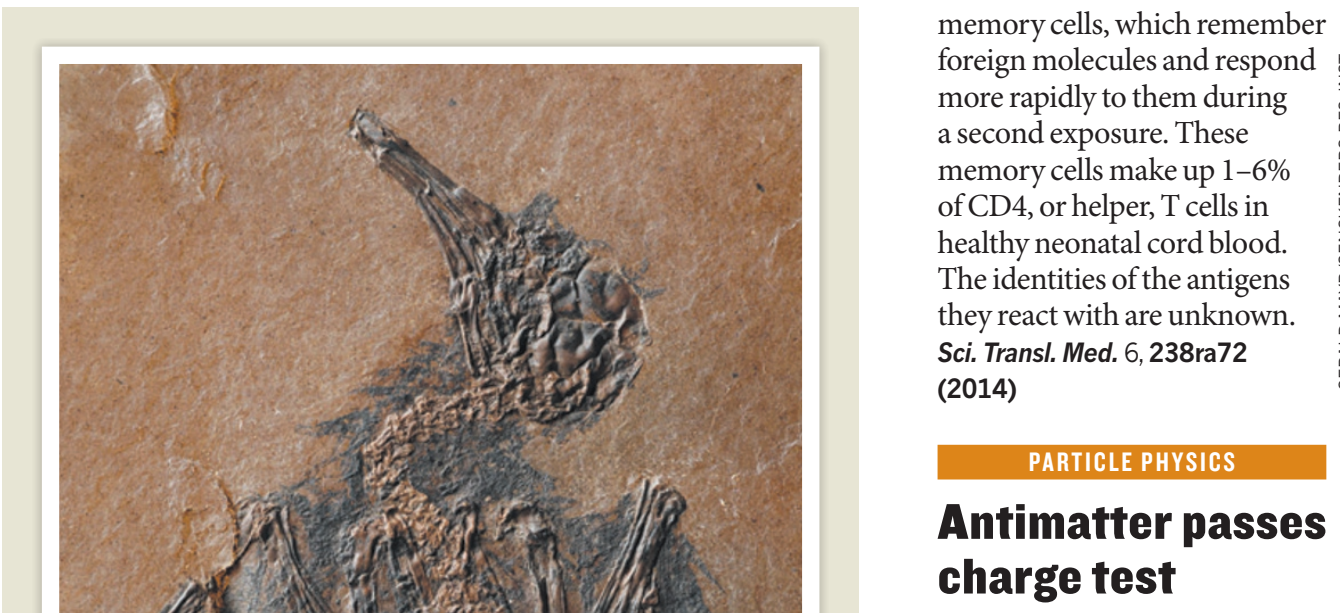

Physicists have tightened the limits on the possible charge of an atom of antihydrogen.

The neutral charge on many atoms and molecules has been measured with extremely high precision. The standard model of physics says that hydrogen's antimatter counterpart should have an opposite charge and so be neutral to a similar level. Any differences between the two could help to explain why the Universe contains more matter than antimatter.

Joel Fajans at the University of California, Berkeley, and his colleagues used data from previous experiments to analyse the influence of electric fields on antihydrogen atoms released from a magnetic trap. They found that the atom was chargeneutral, with a limit 1 million times lower than the best previous figure.

Nature Commun. http://dx.doi. org/10.1038/ncomms4955 (2014) other nectar-slurping birds, such as hummingbirds. Electron microscopy revealed pollen grains in the bird's stomach (boxed).

P. tessellatus is not closely related to present-day nectarfeeding birds, suggesting that interactions between birds and flowers predate those species, the authors say. Biol. Lett. http://doi.org/szj (2014) is presumed to be sterile.

Human T cells begin to form

when the fetus is about ten weeks old, but the cells were thought to remain unexposed to foreign antigens until after birth. However, Richard Lo-Man of the Pasteur Institute in Paris and his team found a subset of fetal T cells known as 


\section{David}

Mouillot at

Montpellier

University

in France and

his colleagues used

sediment cores to map

coral reef habitats over the

past 3 million years and compared this analysis with

the current distribution of more than 6,000 reef fish species. The team found that the historical proximity of the fish habitats to stable coral reefs during cold periods had a greater influence on current patterns of reef fish diversity than present-day environmental factors such as sea-surface temperature. The diversity of damselfishes (Pomacentridae, pictured) in particular was strongly linked to their distance from coral reef refuges.

As the climate warms, conservation biologists should focus on protecting coral reefs that connect historical refuges.

Science 344, 1016-1019 (2014)

\section{GEOLOGY}

\section{First crust looked} like Iceland

Ancient rocks from Canada suggest that Earth's first land was made billions of years ago in the same way as Iceland.

Geologists think that continental crust first formed as magma broke through the dense ocean crust and crystallized on top. Iceland is considered to be the best modern analogue of early continental crust formation, but until now no ancient rocks have been found with the same chemistry as Icelandic ones. Jesse Reimink and his colleagues at the University of Alberta in Edmonton, Canada, discovered that 4.02-billion-year-old rocks in northwestern Canada share the same geochemical signatures as rocks from Iceland, but have signatures that are distinct from 3.9-billion- to 2.5-billionyear-old rocks.
The Canadian rocks were probably formed as magma cooled and

solidified in shallow waters, the scientists say.

Nature Geosci. http://doi.org/ szb (2014)

\section{NEUROPROSTHETICS}

\section{Brain signals move paralysed hand}

Paralysed monkeys were able to move their hands after researchers rerouted brain signals into the animals' spinal cord.

Jonas Zimmermann and Andrew Jackson at Newcastle University, UK, implanted recording electrodes in the premotor cortex area of the brains of two monkeys and stimulating electrodes in the monkeys' spinal cords. The authors trained the animals to pull a lever for a food reward and then temporarily paralysed them by injecting a chemical into the motor cortex.

When the paralysed monkeys tried to pull the lever, a computer program translated the electrical impulses from the brain into stimulation signals that were transmitted to the spinal cord. The animals could move the lever a greater distance and more frequently when the signals were transmitted compared with when they were not.

The approach could one day be used to make paralysed human limbs perform a variety of tasks, the authors say.

Front. Neurosci. 8, 87 (2014)

ATMOSPHERIC SCIENCE

\section{Climate concerns from refrigerants}

Chemicals that are slowly escaping from refrigerators and air conditioners are a greater threat to the climate than previously thought.

Hydrofluorocarbons (HFCs) are refrigerants that are replacing banned ozonedepleting chemicals. But HFCs are also greenhouse gases, and the amount of

\section{SOCIAL SELECTION Rominaranical}

\section{Winner takes all in science}

Many researchers on Twitter have been sharing an article that supports their hard-won observations: science funding doesn't always go to the most deserving. The article, by sociologist Yu Xie at the University of Michigan in Ann Arbor, notes that science now resembles a "winner-takes-all" system that awards a disproportionate share of resources to a minority of researchers and institutions. Timothy O'Leary, a neuroscientist at Brandeis University in Waltham, Massachusetts, tweeted that "inequality is OK provided the $90 \%$ can make a living". But even that is proving difficult. "Postdocs are having permanent conversations about making the transition out of science," he says. "They have to move up or move out."

Xie, Y. Science 344, 809-810 (2014)

\begin{tabular}{l|l}
\hline $\begin{array}{l}\text { Based on data from altmetric.com. } \\
\text { Altmetric is supported by Macmillan }\end{array}$ & For more on \\
$\begin{array}{l}\text { Science and Education, which owns } \\
\text { Nature Publishing Group. }\end{array}$ & $\begin{array}{l}\text { popular papers: } \\
\text { go.nature.com/f79a6z }\end{array}$ \\
\hline
\end{tabular}

these chemicals stored in refrigeration equipment is increasing. Guus Velders at the National Institute for Public Health and the Environment in Bilthoven, the Netherlands, and his colleagues analysed different scenarios for reducing HFCs, either by phasing out production or by destroying HFC-containing equipment.

They found that phasing out production of HFCs early, such as by 2020 , would provide the greatest environmental benefit. If the phase-out were to occur later, millions of refrigeration and air-conditioning units would need to be destroyed to achieve the same benefit.

Atmos. Chem. Phys. 14,

4563-4572 (2014)

\section{CLIMATE CHANGE}

\section{Fading winter fog threatens crops}

Climate change has reduced the amount of winter fog in California (pictured), possibly damaging the region's fruit and nut crops.

Much of the fruit and nut production in the United States comes from the Central Valley of California. Dennis

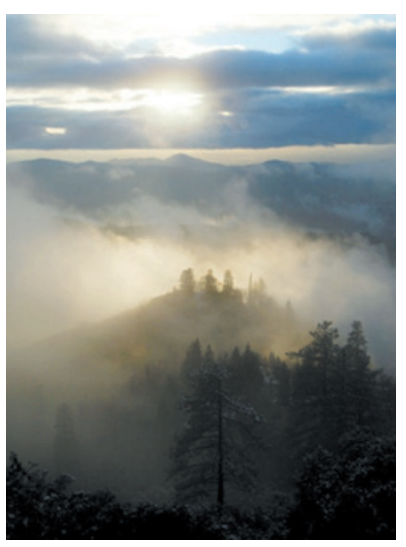

Baldocchi and Eric Waller at the University of California, Berkeley, analysed 33 years of satellite data and found that the number of winter fog events in this region decreased by $46 \%$ on average over 32 winters.

Winters with less fog will yield fewer hours of winter chill, which fruit and nut trees need in order to rest and prepare for the next growing season.

Geophys. Res. Lett. http://doi. org/szk (2014)

\section{$\rightarrow$ NATURE.COM}

For the latest research published by Naturevisit:

www.nature.com/latestresearch 